\title{
9562_UA
}

\section{The results of seismic observations in the central part of the Ukrainian shield in 2007-2013}

*V. Omelchenko, A. Kendzera, V. Kuchma (Institute of Geophysics by S.I. Subbotin name of NAS of Ukraine)

SUMMARY

The results of the analysis of seismic events recorded in the Ukrainian Shield from 2007 to 2013 are presented. The comparison of seismic activity with the deep structure of the Earth's crust and tectonic features of the region was accomplished.

\section{Результати сейсмічних спостережень в центральній частині Українського щита в 2007-2013 рр.}

*В.Д. Омельченко, О.В. Кендзера, В.Г. Кучма (Інститут геофізики ім. С.І. Субботіна НАН України)

PEЗЮME

Наведено результати аналізу сейсмічних подій, зареєстрованих на Українському щиті з 2007 до 2013 р. Проведено співставлення сейсмічної активності з глибинною будовою земної кори та тектонічними особливостями регіону. 
Об’єкт досліджень - сейсмічні події на території Українського щита (УЩ).

Мета роботи - вивчення сейсмічності, сейсмічної небезпеки та геодинаміки території Українського щита і суміжних районів; забезпечення об'єктивними даними робіт в галузі сейсмічного захисту населення; вивчення глибинної будови і динаміки земної кори. Одержаний досвід буде використано для вироблення та обгрунтування організаційних заходів 3 підвищення сейсмічної безпеки регіонів України.

Методи дослідження: збір і аналіз даних спостережень за проявом геофізичних полів на досліджуваній території. Моделювання геофізичних полів, статистичні методи аналізу цифрових рядів даних.

В центральній частині УЩ протягом 2007 - 2013 рр. проведено вивчення форми записів та спектрограм місцевих сейсмічних подій з магнітудою $m b \geq 2,0$ з метою встановлення їх природи. Використано записи сейсмічних подій, епіцентри яких знаходяться в західній частині Східно-Свропейської платформи (ССП) і на Українському щиті (УЩ). Згідно з результатами аналізу спектрограм, встановлено, що основна маса місцевих сейсмічних подій - потужні промислові вибухи в кар'єрах. За період 2007 - 2013 рр. в цьому районі зареєстровано 12 сейсмічних подій тектонічного походження з $\mathrm{mb}=2,0-4,6$ та понад 10 тисяч промислових вибухів $3 m b \geq 1,0$. Магнітуда 16 найбільш потужних вибухів, проведених в $2011-2012$ pр. в кар'єрах і шахтах УЩ, знаходиться в інтервалі значень 3,0 - 3,9. Зроблено співставлення цього матеріалу 3 даними, одержаними станціями сейсмічної мережі Карпатської досліднометодичної сейсмічної партії ІГФ НАНУ; деякі з них розташовані на платформі поблизу південно-західного краю УЩ.

\section{Основні напрямки проведених досліджень:}

- встановлення зв’язку розташування епіцентрів локальних землетрусів з тектонікою в УЩ;

- характеристика сейсмічних подій в центральній частині УЩ;

- результати вивчення записів промислових вибухів на УЩ в кар'єрах і шахтах;

- узагальнення геолого-геофізичних даних про будову земної кори в районі м. Кривий Ріг;

- аналіз природи землетрусів, які відбулися в центральній частині УЩ, та впливу техногенного фактору на прояви локальної сейсмічності в районі Криворізької залізорудної структури;

Форма записів та спектрограми локальних землетрусів і промислових вибухів в кар'єрах та шахтах на платформній частині території України, зареєстрованих сейсмічними станціями, має суттєві відмінності.

Місцеві землетруси 2009 - 2011 рр. та попередніх років, вогнища яких знаходяться на південно-західному краї УЩ в зоні перетину глибинних розломів, в деякій мірі пов'язані $з$ побудовою гідроелектростанції (ГЕС). Перші землетруси в цьому районі виникли в 1984 р. при заповненні котловини водою, їх магнітуда дорівнювала $3,6-3,8$. На протязі наступних п’яти років серед слабких сейсмічних поштовхів спостерігалися сильні з магнітудою $m_{b}=3,1-3,4$. В останні 23 роки максимальна магнітуда не перевищила значення 2,7, тобто в даний період відбувається згасання тектонічного процесу, який виник в зоні розломів земної кори в зв'язку $з$ порушенням геодинамічної рівноваги при побудові та перших етапах роботи ГЕС. Виявлено зв'язок місцевої сейсмічності, встановленої в зонах тектонічних порушень земної кори, 3 проведенням масових промислових вибухів у кар'єрах, змінами рівня води в районах ГЕС під час скиду іï з греблі та іншими факторами.

В центральній частині УЩ в Криворізько-Кременчуцькій залізорудній структурі на протязі 2007 - 2013 рр. зареєстровано три землетруси з магнітудою > 3,5. Під час одного з них, 
що відбувся 13 червня 2010 р. $\left(m_{b}=4,3\right)$, сталося просідання земної поверхні на значній території; в межах м. Кривий Ріг виникли провали глибиною $10-80$ м. Цей землетрус $\epsilon$ наслідком вибуху, проведеного в шахті в інтервалі глибини $447-527$ м.

В зв'язку з інтенсивністю гірничих робіт в Криворіжжі в другій половині XX ст. та їх наслідками, були проведені кількісні оцінки змін геологічного середовища під впливом природних процесів та дією техногенно-природних і техногенних факторів. Вивчено границі деформацій поверхні, що пов'язані з глибиною і площею виробіток з врахуванням умов залягання порід і тектонічних порушень. Відзначено, що екстенсивна експлуатація родовищ в залізорудному басейні обумовлює катастрофічне порушення еколого-геологічної обстановки; на вузькій смузі (протяжністю більше 100 км) концентрація велетенських гірничодобувних підприємств перевищила допустимі норми; перед м. Кривий Ріг виникла перспектива екологічного колапсу. В 90-х роках XX ст. значно збільшилася площа земель, які відійшли під об'єкти гірничодобувної промисловості. В районі м. Кривий Ріг відчужено майже 70 тис. га площі земель, в той час як в першій половині століття лише 50 тис. га було відчужено. На кожного жителя міста вже в 90-х роках припадало близько 5 т шкідливих речовин.

В наступні роки ситуація не змінювалася, відчуження земель продовжувалося, потужність вибухів зростала. Зокрема на протязі 2011, 2012 рр. станціями сейсмічної мережі зареєстровано 9 вибухів з $m_{b} \geq 3,0$; при двох найсильніших значення магнітуди дорівнювало 3,8 $-3,9$.

Землетруси в м. Кривий Ріг, при яких інтенсивність струшування земної поверхні в епіцентрі становила 5 балів за шкалою MSK-64, відбулися 25 грудня 2007 р. $\left(m_{b}=3,9\right), 14$ січня 2011 p. $\left(m_{b}=3,8\right)$ та 23 червня 2013 p. $\left(m_{b}=4,6\right)$. Виникнення вогнищ землетрусів в районі Криворізько-Кременчуцької зони розломів на границі Інгульського та Середньопридніпровського мегаблоків УЩ імовірно являються наслідком зміни напруги на деяких ділянках земної кори в зв'язку з порушенням геодинамічної рівноваги, заподіяним потужними вибухами підчас наземної і підземної розробки корисних копалин. Вплив вибухових робіт на прояв землетрусів обгрунтовується збігом часу реєстрації перших двох 3 них $з$ часом проведення потужних вибухів в шахтах. Виняток - найбільш сильний землетрус 23 червня 2013 р., який відбувся в 24 години 16 хвилин за Київським часом; в нічні часи доби вибухові роботи не проводяться, крім того на протязі першої половини 2013 р. не зареєстровано вибухів $3 m_{b} \geq 3,0$. Магнітуда при двох найбільш потужних вибухах не перевищила значення 2,4 .

Глибина вогнищ землетрусів 2007 - 2013 pp. (10 - 20 км) характеризує нестабільний стан середовища верхнього шару земної кори. Сейсмічні події руйнівного характеру тектонічного і техногенного походження створюють небезпеку для життя населення. Не виключено, що в цьому районі при подальшому продовженні масштабних розробок скупчень корисних покладів із застосуванням підчас вибухових робіт потужних зарядів, можуть відбуватися землетруси 3 магнітудою вище 4,6. 